\title{
ANALISIS EKONOMI USAHA TERNAK KELINCI
}

\author{
Darman \\ Jurusan Manajemen, Fakultas Ekonomi dan Komunikasi, BINUS University \\ Jln. KH Syahdan No. 9, Palmerah, Jakarta Barat 11480 \\ darmanl@binus.ac.id
}

\begin{abstract}
Rabbit livestock development has been started since the 80's and received a positive response from all walks of society and government officials in addressing nutrition fulfillment. The main obstacle in its development is still a psychological effect among men with cattle and rabbits in terms of cutting as well as to eat. On the other animals are prolific rabbit and bear a short distance so as to produce a sufficiently high number of children in a short time unit (per year) so that the meat is known as a reliable provider. Rabbit farm business other than as a fulfillment of nutrition (subsistence) needs the support to lead to market-oriented commercial enterprises. Have tried to do an intensive analysis of enterprise-scale rabbit breeding 20 males and 5 tails as a business producing meat and pelts for one year. The results of the economic analysis suggests that gains on the scale of the business amounted to $R p$ 9.206.200/tahun or Rp 767.183/bulan (in this calculation is carried out an assessment of the remaining rabbit pieces that have not aged, as in cash opnam remaining number of (young cattle).
\end{abstract}

Keywords: economical analysis, rabbit, technology

\begin{abstract}
ABSTRAK
Pengembangan ternak kelinci sudah dimulai sejak tahun 1980an dan mendapat sambutan positif dari berbagai kalangan masyarakat maupun pejabat pemerintah dalam mengatasi pemenuhan gizi. Kendala utama dalam pengembangannya adalah masih adanya pengaruh psikologis antara manusia dengan ternak kelinci dalam hal memotong dan sekaligus untuk dimakan. Di sisi lain ternak kelinci bersifat prolifik dan jarak beranak yang pendek sehingga mampu menghasilkan jumlah anak yang cukup tinggi pada satuan waktu yang singkat (per tahun) sehingga dikenal sebagai penyedia daging yang handal. Usaha peternakan kelinci selain sebagai pemenuhan gizi (subsisten) perlu adanya dukungan untuk mengarah pada usaha komersil berorientasi pasar. Telah dicoba dilakukan analisis terhadap usaha kelinci intensif yang berskala 20 ekor induk dan 5 ekor pejantan sebagai usaha penghasil daging dan kulit bulu selama satu tahun. Hasil analisis ekonomi menunjukkan bahwa keuntungan pada skala usaha tersebut adalah sebesar Rp 9.206.200/tahun atau Rp 767.183/bulan (dalam perhitungan ini dilakukan penilaian terhadap sisa kelinci yang belum berumur potong, karena dalam kas opnam masih tersisa sejumlah (ternak muda).
\end{abstract}

Kata kunci: analisis ekonomi, kelinci, teknologi 


\section{PENDAHULUAN}

Ternak ini semula hewan liar yang sulit dijinakkan. Kelinci dijinakkan sejak 2000 tahun silam dengan tujuan keindahan, bahan pangan dan sebagai hewan percobaan. Hampir setiap negara di dunia memiliki ternak kelinci karena kelinci mempunyai daya adaptasi tubuh yang relatif tinggi sehingga mampu hidup di hamper seluruh dunia. Kelinci dikembangkan di daerah dengan populasi penduduk relatif tinggi, Adanya penyebaran kelinci juga menimbulkan sebutan yang berbeda, di Eropa disebut rabbit, Indonesia disebut kelinci, Jawa disebut trewelu dan sebagainya. Di Indonesia masih terbatas daerah tertentu dan belum menjadi sentra produksi/dengan kata lain pemeliharaan masih tradisional.

Menurut sistem Binomial, bangsa kelinci diklasifikasikan sebagai: (1) Ordo: Lagomorpha; (2) Famili: Leporidae; (3) Sub family: Leporine; (4) Genus : Lepus, Orictolagus; dan (5) Spesies: Lepus spp., Orictolagus spp.

Jenis yang umum diternakkan adalah American Chinchilla, Angora, Belgian, Californian, Dutch, English Spot, Flemish Giant, Havana, Himalayan, New Zealand Red, White dan Black, Rex Amerika. Kelinci lokal yang ada sebenarnya berasal dari dari Eropa yang telah bercampur dengan jenis lain hingga sulit dikenali lagi. Jenis New Zealand White dan Californian sangat baik untuk produksi daging, sedangkan Angora baik untuk bulu. Manfaat yang diambil dari kelinci adalah bulu dan daging yang sampai saat ini mulai laku keras di pasaran. Selain itu hasil ikutan masih dapat dimanfaatkan untuk pupuk, kerajinan dan pakan ternak.

Keberadaan ternak kelinci bagi manusia dapat dimanfaatkan dalam berbagai hasil produk. Hasil pemotongan ternak kelinci menghasilkan daging dan kulit bulu. Melalui serangkaian kegiatan (proses) dan penambahan beberapa bahan lain maka dapat dihasilkan bahan pangan (nugget, baso, burger, sosis, sate, dan lain-lain.) maupun bahan industri kerajinan kuli (tas, mantel, hiasan, dll.). Produk lain dari ternak kelinci adalah ternak sebagai binatang kesayangan dan penghasil kotoran untuk pupuk. Beberapa tipe kelinci sebagai ternak kesayangan mempunyai nilai harga harga yang lebih baik dibanding ternak kelinci pedaging. Sedangkan kotoran ternak (feses, air kencing dan sisa hijauan) setelah diproses menjadi kompos berguna sebagai penyubur tanah maupun tanaman (Sartika, 1998).

Farel dan Raharjo (1994) mengatakan bahwa kelinci sapihan dapat menghasilkan kotoran sebanyak 28 gram kotoran lunak atau setara dengan 3 gram protein/hari/ekor. Penggunaan kotoran kelinci dengan tambahan probiotik (kompos) berguna untuk kesuburan tanah dan tanaman dan telah dilakukan percobaan skala penelitian. Sajimin et al. (2005) mengatakan bahwa penggunaan kompos kelinci dengan feses kelinci ditambah probiotik kandungan bahan organik dengan $\mathrm{C} / \mathrm{N}$ ratio (11-12\%) lebih baik dibanding tanpa probion $\mathrm{C} / \mathrm{N}$ (10\%). Manfaat lain adalah kompos feses kelinci dapat meningkatkan pertumbuhan dan produksi tanaman Stylosanthes hamata secara nyata lebih tinggi 58,4\% dibandingkan dengan tanpa probiotik. Industri pengolahan ternak kelinci meliputi: teknologi pengolahan daging (nuget, sosis, burger, dendeng, baso, sate, gule, tongseng, soup). Sedangkan kulit dan buluh kelinci dapat diolah menjadi bahan kerajinan hiasan dan souvenir (gantungan kunci, pajangan yang berupa wayang kulit) dan pakaian seperti mantel/jaket. Selain itu kotoran ternak kelinci dapat dijadikan pupuk kompos (Lokakarya Nasional Potensi dan Peluang Pengembangan Usaha Kelinci, 141).

Menurut Sartika et al. (1998) dari seekor induk yang dipelihara selama 1 tahun dapat menghasilkan sebanyak $117 \mathrm{~kg}$ daging untuk kelinci Ras biasa dan $144 \mathrm{~kg}$ daging untuk kelinci Hybreed pada pemeliharaan secara intensif dan manajemen yang baik. Hal tersebut dikarenakan ternak kelinci bersifat prolifik dan jarak antar kelahiran yang cukup pendek. Sedangkan prosentase karkas kelinci mencapai 42,6 sampai $46,7 \%$. 
Menurut Farel \& Raharjo (1994) bahwa daging kelinci mempunyai kualitas kandungan gizi yang cukup baik, karena mengandung lemak, kolesterol dan garam yang rendah. Dalam kajiannya tentang preferensi daging kelinci yang dilakukan oleh Diwyanto et al. (1985) diperoleh hasil bahwa warna, aroma, rasa dan keempukan daging kelinci panggang antara berbagai jenis kelinci tidak berbeda nyata. Selanjutnya dikatakan antara warna, aroma dan rasa daging kelinci dengan ayam ras tidak menunjukkan hasil yang berbeda, kecuali keempukan dimana ternak ayam lebih empuk.

\section{METODE}

Metode penelitian yang dilakukan adalah metode survey, metode perpustakaan dan berdasarkan pengalaman penulis sendiri sebagai peternak kelinci. Metode survei dilakukan dengan mengunjungi beberapa peternak kelinci dalam skala kecil (>10 ekor) dan skala menengah $(>100$ ekor). Model analisis yang dilakukan adalah analisis input-output pertahun yang terdiri dari komponen biaya (kandang dan perlengkapan, bibit, pakan dan obat-obatan) dan pendapatan. Selisih pendapatan dan biaya merupakan nilai keuntungan dan kemudian dilanjutkan dengan analisis $\mathrm{R} / \mathrm{C}$ ratio. Model analisis lain yang dilakukan adalah analisis SWOT. Dari analisis ini, dapat digambarkan potensi dan peluang usaha peternakan kelinci yang sangat menjanjikan dan juga akan menjadi ancaman jika usaha ternak kelinci tidak dulakukan dengan optimal.

\section{HASIL DAN PEMBAHASAN}

\section{Pedoman Teknis Budidaya}

Yang perlu diperhatikan dalam usaha ternak kelinci adalah persiapan lokasi yang sesuai, pembuatan kandang, penyediaan bibit dan penyediaan pakan. Fungsi kandang sebagai tempat berkembangbiak dengan suhu ideal $21^{\circ} \mathrm{C}$, sirkulasi udara lancar, lama pencahayaan ideal 12 jam dan melindungi ternak dari predator.

Menurut kegunaan, kandang kelinci dibedakan menjadi kandang induk. Untuk induk/kelinci dewasa atau induk dan anak-anaknya, kandang jantan, khusus untukpejantan dengan ukuran lebih besar dan Kandang anak lepas sapih. Untuk menghindari perkawinan awal kelompok dilakukan pemisahan antara jantan danbetina. Kandang berukuran 200x70x70 cm tinggi alas $50 \mathrm{~cm}$ cukup untuk 12 ekor betina/10 ekor jantan. Kandang anak (kotak beranak) ukuran 50x30x45 cm.

Menurut bentuknya kandang kelinci dibagi menjadi: (1) kandang sistem postal, tanpa halaman pengumbaran, ditempatkan dalam ruangan dan cocok untuk kelinci muda; (2) kandang sistem ranch, dilengkapi dengan halaman pengumbaran; dan (3) kandang battery, mirip sangkar berderet di mana satu sangkar untuk satu ekordengan konstruksi Flatdech Battery (berjajar), Tier Battery (bertingkat), Pyramidal Battery (susun piramid). Perlengkapan kandang yang diperlukan adalah tempat pakan dan minum yangtahan pecah dan mudah dibersihkan.

Untuk syarat ternak tergantung dari tujuan utama pemeliharaan kelinci tersebut.Untuk tujuan jenis bulu maka jenis Angora, American Chinchilla dan Rex merupakan ternak yang cocok. Sedang untuk tujuan daging maka jenis Belgian, Californian, Flemish Giant, Havana, Himalayan dan New Zealand merupakan ternak yang cocok dipelihara. 


\section{Pemilihan bibit dan calon induk}

Bila peternakan bertujuan untuk daging, dipilih jenis kelinci yang berbobot badan dan tinggi dengan perdagingan yang baik, sedangkan untuk tujuan bulu jelas memilih bibit-bibit yang punya potensi genetik pertumbuhan bulu yang baik. Secara spesifik untuk keduanya harus punya sifat fertilitas tinggi, tidakmudah nervous, tidak cacat, mata bersih dan terawat, bulu tidak kusam, lincah/aktif bergerak.

\section{Perawatan Bibit dan calon induk}

Perawatan bibit menentukan kualitas induk yang baik pula, oleh karena itu perawatan utama yang perlu perhatian adalah pemberian pakan yang cukup, pengaturan dan sanitasi kandang yang baik serta mencegah kandang dari gangguan luar.

\section{Sistem Pembiakan}

Untuk mendapat keturunan yang lebih baik dan mempertahankan sifat yang spesifik maka pembiakan dibedakan dalam 3 kategori yaitu: (1) In Breeding (silang dalam), untuk mempertahankan dan menonjolkansifat spesifik misalnya bulu, proporsi daging; (2) Cross Breeding (silang luar), untuk mendapatkan keturunan lebih baik/menambah sifat-sifat unggul; (3) Pure Line Breeding (silang antara bibit murai), untuk mendapat bangsa/jenis baru yang diharapkan memiliki penampilan yang merupakan perpaduan 2 keunggulan bibit.

\section{Reproduksi dan Perkawinan}

Kelinci betina segera dikawinkan ketika mencapai dewasa pada umur 5 bulan (betina dan jantan). Bila terlalu muda kesehatan terganggu dan mortalitas anak tinggi. Bila pejantan pertama kali mengawini, sebaiknya kawinkan dengan betina yang sudah pernah beranak. Waktu kawin pagi/sore hari di kandang pejantan dan biarkan hingga terjadi 2 kali perkawinan, setelah itu pejantan dipisahkan.

\section{Proses Kelahiran}

Setelah perkawinan kelinci akan mengalami kebuntingan selama 30-32 hari. Kebuntingan pada kelinci dapat dideteksi dengan meraba perut kelinci betina 12-14 hari setelah perkawinan, bila terasa ada bola-bola kecil berarti terjadi kebuntingan. Lima hari menjelang kelahiran induk dipindah ke kandang beranak untuk memberi kesempatan menyiapkan penghangat dengan cara merontokkan bulunya. Kelahiran kelinci yang sering terjadi malam hari dengan kondisi anak lemah, mata tertutup dan tidak berbulu. Jumlah anak yang dilahirkan bervariasi sekitar 6-10 ekor.

\section{Pemeliharaan}

Tempat pemeliharaan diusahakan selalu kering agar tidak jadi sarang penyakit. Tempat yang lembab dan basah menyebabkan kelinci mudah pilek dan terserang penyakit kulit. Kelinci yang terserang penyakit umumnya punya gejala lesu, nafsu makan turun, suhu badan naik dan mata sayu. Bila kelinci menunjukkan hal ini segera dikarantinakan dan benda pencemar juga segera disingkirkan untuk mencegah wabah penyakit. Penyapihan anak kelinci dilakukan setelah umur 7-8 minggu. Anak sapihan ditempatkan kandang tersendiri dengan isi 2-3 ekor/kandang dan disediakan pakan yang cukup dan berkualitas. Pemisahan berdasar kelamin perlu untuk mencegah dewasa yang terlalu dini. Pengebirian dapat dilakukan saat menjelang dewasa. Umumnya dilakukan pada kelinci jantan dengan membuang testisnya.

Jenis pakan yang diberikan meliputi hijauan meliputi rumput lapangan, rumput gajah, sayuran meliputi kol, sawi, kangkung, daun kacang, daun turi dan daun kacang panjang, biji-bijian/pakan penguat meliputi jagung, kacang hijau, padi, kacang tanah, sorghum, dedak dan bungkil-bungkilan. 
Untuk memenuhi pakan ini perlu pakan tambahn berupa konsentrat yang dapat dibeli di toko pakan ternak. Pakan dan minum diberikan dipagi hari sekitar pukul 10.00. Kelinci diberi pakan dedak yang dicampur sedikit air. Pukul 13.00 diberi rumput sedikit/secukupnya dan pukul 18.00 rumput diberikan dalam jumlah yang lebih banyak. Pemberian air minum perlu disediakan di kandang untuk mencukupi kebutuhan cairan tubuhnya.

\section{Hama dan Penyakit}

Hama dan penyakit yang terdapat dalam peternakan kelinci: (1) bisul, penyebab terjadinya Pengumpulan darah kotor di bawah kulit. Pengendalian: pembedahan dan pengeluaran darah kotor selanjutnya diberi Jodium. (2) Kudis, penyebab : Darcoptes scabiei. Gejala: ditandai dengan koreng di tubuh. Pengendalian: dengan antibiotik salep; (3) Eksim, penyebab: kotoran yang menempel di kulit. Pengendalian: menggunakan salep/bedak Salicyl; (4) Penyakit telinga, penyebab: kutu. Pengendalian: meneteskan minyak nabati; (5) Penyakit kulit kepala, penyebab: jamur. Gejala: timbul semacam sisik pada kepala. Pengendalian: dengan bubuk belerang; (6) Penyakit mata, penyebab: bakteri dan debu. Gejala: mata basah dan berair terus. Pengendalian: dengan salep mata; (7) Mastitis, penyebab: susu yang keluar sedikit/tak dapat keluar. Gejala: puting mengeras dan panas bila dipegang. Pengendalian: dengan tidak menyapih anak terlalu mendadak. (8) Pilek, penyebab: virus. Gejala: hidung berair terus. Pengendalian: penyemprotan antiseptik pada hidung; (9) Radang paru-paru, penyebab: bakteri Pasteurella multocida. Gejala: napas sesak, mata dan telinga kebiruan. Pengendalian: diberi minum Sul-Q-nox; (10) Berak darah, penyebab: protozoa Eimeira. Gejala: nafsu makan hilang, tubuh kurus, perut membesar dan mencret darah. Pengendalian: diberi minum sulfaquinxalin dosis $12 \mathrm{ml}$ dalam 1 liter air; (11) Hama pada kelinci umumnya merupakan predator dari kelinci seperti anjing. Pada umumnya pencegahan dan pengendalian hama dan penyakit dilakukan dengan menjaga kebersihan lingkungan kandang, pemberian pakan yang sesuai dan memenuhi gizi dan penyingkiran sesegera mungkin ternak yang sakit.

\section{Panen} pupuk.

Hasil utama saat panen adalah: daging dan bulu. Hasil tambahannya yaitu kotoran untuk

\section{Pasca Panen}

Saat pasca panen, dilakukan beberapa langkah, seperti: (1) Stoving, kelinci dipuasakan 6-10 jam sebelum potong untuk mengosongkan usus. Pemberian minum tetap. (2) Pemotongan, dapat dengan 3 cara yaitu (a) Pemukulan pendahuluan, kelinci dipukul dengan benda tumpul pada kepala dan saat koma disembelih (b) Pematahan tulang leher, dipatahkan dengan tarikan pada tulang leher (cara ini kurang baik), (c) Pemotongan biasa, sama seperti memotong ternak lain. (3) Pengulitan, dilaksanakan mulai dari kaki belakang ke arah kepala dengan posisi kelinci digantung. (4) Pengeluaran Jeroan, kulit perut disayat dari pusar ke ekor kemudian jeroan seperti usus, jantung dan paruparu dikeluarkan. Yang perlu diperhatikan kandung kemih jangan sampai pecah karena dapat mempengaruhi kualitas karkas. (5) Pemotongan Karkas, kelinci dipotong jadi 8 bagian, 2 potong kaki depan, 2 potong kaki belakang, 2 potong bagian dada dan 2 potong bagian belakang. Presentase karkas yang baik adalah $49-52 \%$.

\section{Kendala Pengembangan}

Sastrodihardjo et al. (1992) mengatakan bahwa beberapa kendala pengembangan kelinci antara lain: (1) daging kelinci belum memasyarakat; (2) harga dagingnya belum terjangkau oleh daya beli masyarakat; dan (3) kurang gencarnya promosi tentang perlunya masyarakat mengkonsumsi daging kelinci. Kendala nonteknis diduga lebih kuat pada pengembangan kelinci sebagaimana 
diutarakan oleh Sartika et al. (1998) yang mengatakan ditinjau dari segi preferensi sebetulnya daging kelinci tidak mengalami kendala yang serius, namun kendala mengkonsumsi daging kelinci diduga dari segi psikologis yang mengungkapkan adanya rasa sayang, atau kasihan dalam pemotongannya maupun dalam hal memakannya. Kendala secara teknis banyak ditemui tentang faktor kematian yang mencapai lebih dari $20 \%$ pada tingkat umur potong.

Diwyanto et al. (1985) mengatakan bahwa budidaya ternak yang dilakukan masyarakat masih perlu ditingkatkan melalui perbaikan tatalaksana pemeliharaan. Oleh karena itu diperlukan langkah kongkrit untuk memperkecil atau meniadakannya melalui penyuluhan budidaya dan pemahaman terhadap nilai kemanfaatan kelinci bagi kebutuhan gizi masyarakat. Perlu dipertimbangkan terhadap pengadaan tempat pemotongan yang dilokalisir sehingga perasaan kasihan bagi peternak dapat dihindari. Dilain pihak dengan adanya tempat pemotongan khusus ternak kelinci akan mempermudah pengumpulan kulit bulunya.

\section{Pemasaran}

Produk ternak kelinci yang dapat dipasarkan adalah dalam bentuk hidup, bentuk produk segar maupun produk olahan. Transaksi jual-beli kelinci hidup antara produsen dan konsumen dapat berlangsung di lokasi produsen maupun di pasar (pasar umum, pasar hewan, bahkan tempat rekreasi). Ternak yang diperjual belikan mulai dari status lepas sapih hingga ternak siap kawin.

Daerah pemasaran kelinci, mempunyai tingkatan, mulai dari produsen, pedagang/penyalur, konsumen. Pemasaran kelinci di tingkat produsen; transaksi antara peternak dengan pedagang, pedagang melakukan pembelian kelinci kepada produsen (peternak), ternak yang diperjual belikan adalah ternak bibit, siap potong maupun kelinci dewasa. Transaksi yang terjadi pada produsen selain pedagang adalah juga terdapat peternak dimana tujuannya adalah membeli ternak untuk dikembangkan lebih lanjut. Pemasaran di tingkat pedagang; transaksi antara pedagang dengan konsumen akhir (lokal maupun luar daerah), transaksi seperti ini dilakukan ditempat tertentu (pasar umum, maupun pasar hewan, dan tempat pariwisata daerah). Pemasaran di tingkat konsumen biasnya langsung diolah oleh pedagang-pedagang masakan yang mengolah makanan yang terbuat dari daging kelinci seperti: sate, soup, dan tongseng kelinci yang menjual makanannya kepada konsumen penyuka masakan tersebut.

Pemasaran kelinci biasanya juga banyak terdapat dilokasi pariwisata seperti: Kebun Raya, tempat-tempat wisata pegunungan. Komoditas ternak kelinci yang diperjual belikan didominasi oleh ternak kelinci usia sapih. Namun demikian terdapat pula daerah pariwisata tertentu yang mempunyai ciri tertentu pada komoditas kelinci yaitu sate kelinci di Tawang Mangu, Jawa Tengah, daerah lainnya seperti di Lembang terdapat banyak penjaja tukang sate kelinci di pingggiran jalan.Pemasaran produk daging; pasar dagingkelinci belum banyak dan populer bila dibandingkan dengan daging ternak lain (sapi, kambing dan ayam). Pemasaran daging kelinci perlu usaha yang gigih dan dilakukan melalui usaha-usaha promosi antara lain: melakukan demo pada berbagai instansi tertentu dalam acara seremonial (ulang tahun kemerdekaan atau pameran pembangunan daerah). Peluang akan diterima oleh masyarakat lebih terbuka bila daging kelinci diolah menjadi bentuk lain dari yang sekarang ada, bentuk tersebut antara lain: Nugget, Burger, Fried, atau jenis lainnya seperti: abon, baso dan sosis. Bila dijual dalam bentuk daging segar maka hendaknya diwujudkan dalam bentuk potongan yang menarik misalnya: potongan kaki belakang/paha, potongan pinggang, Schnittzel (bagian daging tanpa tulang yang berasal dari kaki depan).

(http://www.sinarharapan.co.id/feature/hobi/2002/071/hob1.html). 


\section{Analisis Usaha}

Pemanfaatan ternak kelinci dan pengolahan produk kelinci telah dapat memberikan keuntungan yang cukup berarti bagi kehidupan masyarakat di pedesaan, terutama pada sentra-sentra produksi di daerah pariwisata. Seberapa jauh nilai keuntungan yang dapat diraih bagi produsen (peternak), apabila peternak di pedesaan akan mengusahakan sebanyak 20 kelinci induk dan lima pejantan selama setahun. Dengan memperhatikan nilai koefisien teknis produktivitas kelinci dari berbagai hasil penelitian sebelumnya oleh para ahli dan nilai jual produk kelinci (daging, kulit bulu dankotoran) saat ini, maka hasil pendapatannya dapat diketahui. Uraian detail analisa ekonomi sederhana terhadap usaha kelinci dengan skala 20 ekor induk dan 5 ekor jantan selama setahun disajikan pada tabel dibawah ini

Perkiraan analisis ekonomi didasarkan pada jumlah ternak per 20 ekor induk:

1. Biaya Produksi

\begin{tabular}{clr}
\hline NO & BIAYA PRODUKSI & JUMLAH (Rp) \\
\hline 1 & Kandang dan perlengkapan & 1.000 .000 \\
2 & Bibit induk 20 ekor @ Rp 30.000 & 600.000 \\
3 & Pejantan 3 ekor @ Rp 20.000 & 60.000 \\
4 & Pakan & 3.000 .000 \\
& - Sayur + rumput Rp 1.000.000 & \\
& - Konsetrat (pakan tambahan) Rp. 2.000.000,- & 1.000 .000 \\
5 & Obat & 3.600 .000 \\
6 & Tenaga kerja 2x12xRp150.000 & 9.260 .000 \\
\hline
\end{tabular}

2. Pendapatan

Kelahiran hidup/induk/tahun $=31$ ekor

\begin{tabular}{clc}
\hline NO & PENJUALAN & JUMLAH (Rp) \\
\hline 1 & Bibit 20 x 15 x Rp20.000 & 6.000 .000 \\
2 & Kelinci potong 20 x 15 x Rp 50.0000 & 15.000 .000 \\
3 & Fases/kotoran & 60.000 \\
4 & Bulu & 750.000 \\
\hline & Jumlah Pendapatan & 21.810 .000 \\
\hline
\end{tabular}

3. Keuntungan Rp. 12.550.000,-

4. Parameter kelayakan usaha

$\mathrm{B} / \mathrm{C}$ ratio $=2,36$

\section{Analisis SWOT}

\section{Kekuatan (Strength)}

Ternak kelinci mudah dipelihara dan mudah diperoleh. Air kencingnya sangat bagus untuk berkembangnya mikro organisme yang sangat bermanfaat untuk tanaman padi. Tenaga kerja tersedia dan semua tani bisa jadi peternak asal paham ternak kelinci dengan cara pelatihan. Kandang sangat sederhana dan bisa dibuat oleh petani sendiri, tanpa harus memakai tenaga keahlian.

\section{Kelemahan (Weakness)}

Petani bila tidak dibekali ketrampilan beternak kelinci dapat menyebabkan kegagalan beternak kelinci. Kesulitan mencari kelinci unggulan, karena sedikitnya ternak. Arena promosi kurang, terutama pupuk dan urine kelinci. 


\section{Peluang (Opportunity)}

Permintaan akan ternak kelinci sedang booming. Kebutuhan petani akan air kencing kelinci sangat banyak, sehingga peluang beternak kelinci sangat menjanjikan. Lahan bisnis tingkat bawah, dimana urine kelinci dijadikan bahan pupuk tanaman padi yang handal.

\section{Ancaman (Threatness)}

Kebutuhan ternak kelinci meningkat tajam, sementara ketersediaan hewan kelinci sedikit yang berakibat kenaikan harga ternak. Ancaman utama yang dihadapi oleh usaha ini adalah peternakan kelinci mulai dikenal konsumen sehingga mempunyai pangsa pasar yang sangat besar, pada umumnya peternakan ini bermodal besar dan mempunyai system manajemen yang baik sehingga menghasilkan produk dari hewan kelinci yang berkualitas baik

\section{Gambaran Peluang Bisnis}

Gerakan peningkatan gizi yang dicanangkan pemerintah terutama yang berasal dari protein hewani sampai saat ini masih belum terpenuhi. Kebutuhan daging kita masih banyak dipenuhi dari impor. Kelinci yang punya keunggulan dalam cepatnya berkembang, mutu daging yang tinggi, pemeliharaan mudah dan rendahnya biaya produksi menjadikan ternak ini sangat potensial untuk dikembangkan. Apalagi didukung dengan permintaan pasar dan harga daging maupun bulu yang cukup tinggi.

Ternak pada waktu kas opnam terdapat sejumlah kelinci hidup berbagai umur, dalam perhitungan diperhitungkan nilai jual kulit bulu dan bobot hidup yang sama dengan ternak usia potong. 2. Biaya kelinci bibit sudah diperhitungkan dalam nilai kelinci afkir. Dari Tabel 1 dapat diuraikan bahwa jumlah pengeluaran usaha kelinci yang terbanyak adalah untuk upah tenaga kerja Sebesar Rp 3.600.000 (38,88\%) dan pembelian pakan Rp 3.000.000/tahun atau 32,40\%. Dari total pengeluaran sebanyak Rp9.260.000/tahun. Sedangkan sumber penerimaan terbanyak diperoleh dari penjualan daging kelinci sebesar Rp 15.000.000 dan penjualan bibit Rp 6.000.000.

Meskipun kotoran kelinci dapat menghasilkan uang, namun nilainya masih cukup sedikit, yaitu sekitar Rp 60.000/tahun. Dari usaha kelinci dengan skala usaha 20 ekor induk dan lima ekor jantan, maka diperoleh pendapatan (keuntungan) sebanyak $R p$ 9.206.200/tahun atau $R p$ 767.183/bulan. Hasil perhitungan pada penerimaan telah mencantumkan tentang ternak kelinci yang masih berusia dibawah umur potong yang terdiri dari umur 5 bulan (144 ekor), umur 3 bulan sebanyak (144 ekor) dan umur 1 bulan sebanyak (160 ekor).

\section{PENUTUP}

Ternak kelinci mempunyai potensi sebgai penghasil daging, kulit bulu, ternak hidup dan kotoran yang sangat bernilai bagi kepentingan manusia. Faktor teknis terutama kematian merupakan kendala pada teknis budidaya, sedangkan faktor nonteknis adalah masalah psikologis dan daya beli mayarakat masih rendah. Promosi pengembangan kelinci melalui pengenalan produk-produk olahan sehingga masyarakat mempunyai pilihan atas produk daging kelinci. Di bidang pertanian dan peternakan, peran teknologi di bidang pascapanen atau pengolahan hasil sangat penting untuk meningkatkan nilai tambahnya. Pengembangan ternak kelinci diharapkan berorientasi komersiil, dengan spesifikasi aktivitas usaha (pembibitan, budidaya dan pengolahan hasil). Usaha kelinci dengan skala 20 ekor induk dan 5 ekor pejantan untuk menghasilkan daging dan kulit bulu dapat diperoleh keuntungan sebesar Rp 9.206.200,-/tahun atau Rp 767.183/bulan (dengan memasukkan penilaian sejumlah kelinci yang masih berusia dibawah umur potong). 


\section{DAFTAR PUSTAKA}

Diwyanto, K., Sumanto, B., Sudaryanto, T., Sartika, \& Darwinsyah. L. (1985). Suatu studi kasus mengenai budidaya ternak kelinci di Desa Pandansari Jawa Tengah: Aspek manajemen dan produktivitas ternak. Ilmu dan Peternakan. Pusat Penelitian dan Pengembangan Peternakan. $1(10)$.

Diwyanto, K., Sartika, T., Moerfiah \& Subandriyo. (1985). Pengaruh persilangan terhadap nilai karkas dan preferensi daging kelinci panggang. Ilmu dan Peternakan. Pusat Penelitian dan Pengembangan Peternakan.1(10).

Farel, D.J., \& Raharjo, Y. C. (1994). Potensi ternak kelinci sebagai penghasil daging. Pusat Penelitian dan Pengembangan Peternakan. Bogor.

Kartadisastra, H. R. (1995). Beternak kelinci unggul. Yogyakarta: Kanisius.

Sajimin, Y. C., Raharjo, N. D., Purwantari \& Lugio. (2005). Produksi tanaman pakan ternak Stylosantethes hamata yang diberi pupuk kelinci. Seminar Nasional Teknologi Peternakan dan Veteriner. Departemen Pertanian. Badan Penelitian dan Pengembangan Pertanian .Puasat Penelitian dan Pengembangan Peternakan. Bogor.

Sartika, T., Antawijaya, T., \& Diwyanto, Y. (1998). Peluang ternak kelinci sebagai sumber daging yang potensial Di Indonesia. Wartazoa 7(2).

Sarwono. B. (1985). Beternak kelinci unggul. Jakarta: Swadaya.

Sastrodihardjo, S., \& Raharjo, Y. C. (1992). Pengkajian kelayakan usaha pembesaran kelinci Rex yang diberi pola pkan berbeda pada lahan pekarangan di dataran tinggi Desa Pandansari, Kabupaten Berebes, Jawa Tengah. Pros. Agro-Industri Peternakan di Pedesaan. Balai Penelitian Ternak, Ciawi. hlm. 150-162.

Yunus, M., \& Minarti, S. (1990). Aneka ternak. Malang: Universitas Brawijaya.

\section{RIWAYAT PENULIS}

Darman lahir di kota Pariaman, Padang, Sumatera Barat, 12 Maret 1959. Penulis menamatkan pendidikan S1 pada Fakultas Ekonomi Universitas Bung Hatta Padang, Jurusan Ilmu Ekonomi dan STUDI Pembangunan tahun 1988 dan S2 pada Fakultas Pasca Sarjana Universitas Borobudur jurusan Manajemen. Saat ini bekerja sebagai dosen tetap Jurusan Manajemen Universitas Bina Nusantara 